\title{
関東平野の基盤構造と重力異常 (2)
}

一活断層の地球物理学的研究—

\author{
国土地理院地殼調査部 多田龿
}

(昭和 58 年 4 月 7 日受理)

\section{Structure of the Basement and the Gravity Anomaly in the Kanto Plain -A Geophysical Study of Active Fault- \\ Takashi TADA \\ Crustal Dynamics Department, Geographical Survey Institute}

(Received Apirl 7, 1983)

Active faults in the Kanto Plain have been studied by the geophysical prospecting method, such as the seismic and the gravity measurements. It is revealed that the active fault is accompanied with the basement fault whose displacement exceeds several hundreds meters in its deeper part. This evidence shows that the geophysical method is a usefull method to detect the burried active fault which is covered by the alluvium. It is concluded that the following order of study, firstly detecting the basement fault by means of the geophysical prospecting method, and secondly carrying out the precise geomorphological, geological and test well surveys, is a practical method for the study of burried active fault in the alluvial plain. Comparing the surface displacement or the displacement velocity of active fault with the displacement of its basement fault makes it possible to estimate the activity of active fault.

\section{§1.はじめに}

関東地方の活断層の研究は数多くあるが，その結果をまとめた総括的報告によれば首都圏の 周辺部についてはかなり詳しく活断層の分布, 活動度が判明してきた [貝塚・他 (1977), 活断 層研究会 (1980)]. 乙かし平野部, 特に首都圈の中央部は厚い堆積層, 地形の人為的改変, 稠 密な人工構造物などのため, 通常の手段による活断層の調査, 研究が困難で, この地域は活断 層の「空白域」になつている.

地震予知の実用化を目指す研究，観測上活断層の調査は重要なことであり，首都圈に於ては 物理探査手法などを積極的に 導入して，活断層の調査，研究を進めることが 要請されている [地震予知連絡会 $(1980)]$.

前報 [多田 (1982)] では関東平野地下に埋もれている断層を検出するために地震探査, 重力 探查，深層ボーリングなどの物理探査データを基に関東平野の基盤構造を調べたが，この続報 


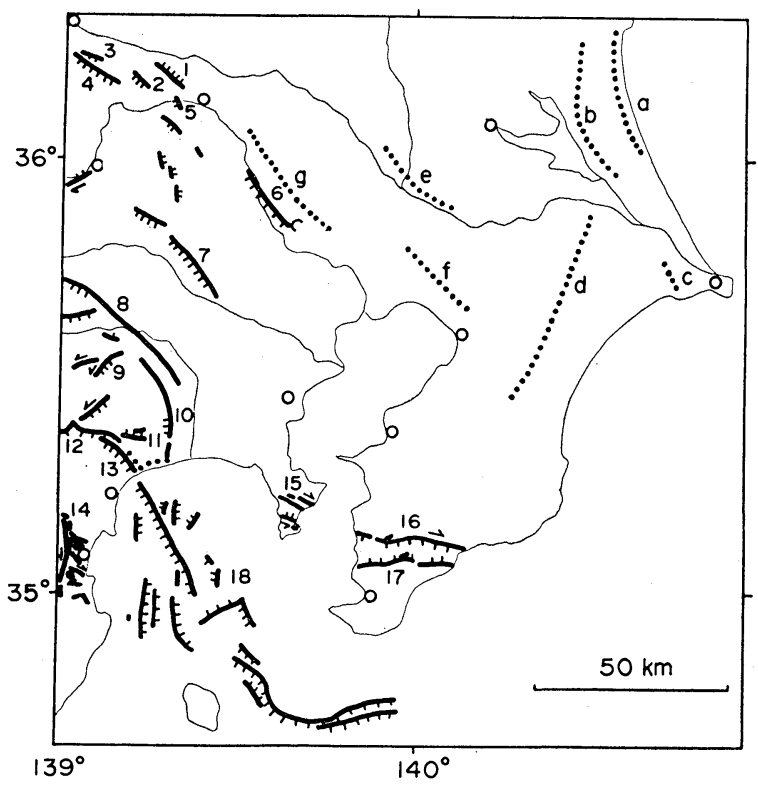

Fig. 1. Active faults in the Kanto district (after Coordinating Committee for Earthquake Prediction, 1980).

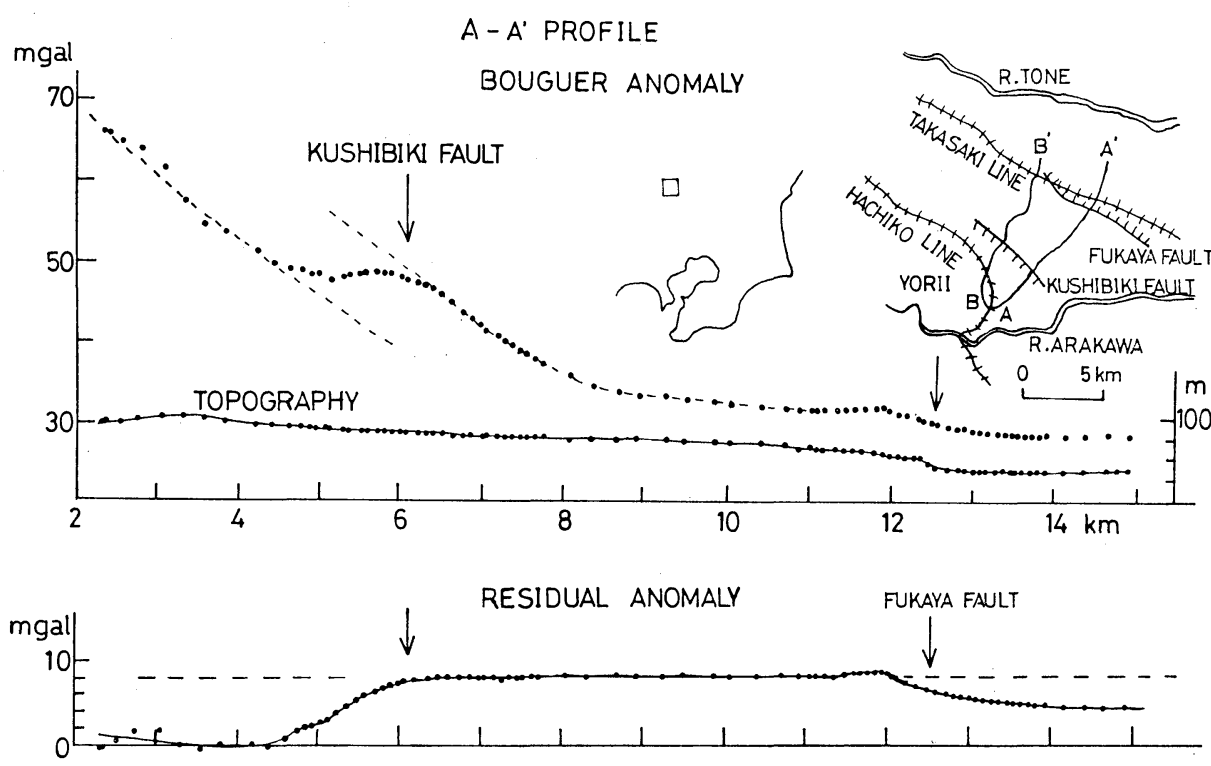

Fig. 2. Bouguer gravity anomaly and residual gravity anomaly in the $A-A^{\prime}$ profile across the Kushibiki and the Fukaya faults. Inserted figuers are location maps of the faults and the gravity measuring routes. 
では基盤構造と活断層との関係などについて述べる.

\section{$\S 2$. 櫛挽断層, 深谷断層と重力異常}

櫛挽断層 (Fig. 1-2) は埼玉県美里村古郡付近から松久丘陵の南西部を横断して櫛挽台地の北 西部まで明瞭な断層地形を示す確実度 I, 活動度 B 級, 北東側隆起, 長さ $5 \mathrm{~km}$ の活断層で ある [活断層研究会 (1980)]．深谷断層 (Fig. 1-1) は埼玉県深谷市の国鉄深谷駅西側の比高約 $10 \mathrm{~m}$ の崖によつてその存在を知ることができる。この断層崖の北西延長部は岡部町岡まで, 南東延長部は熊ヶ谷市三ヶ尻まで地形的に追跡できるが，それ以南では荒川の沖積面のため不 明となる [松田 (時) ・他 (1975)]. 深谷断層は確実度 I, 活動度 B 級, 長さ $10 \mathrm{~km}$ の活断層 で，他の断層と異なつて南西側隆起である [活断層研究会 (1980)].

国土地理院では活断層の活動度を断層の深部構造から推定する目的で櫛挽, 深谷断層で重力 測量を実施した [多田・他 (1978)]．測定間隔は断層近傍で $100 \mathrm{~m}$ その他では $300 \mathrm{~m}$ で，合 計 180 点での測定を行い，ブーゲ重力異常を求めた。 その結果を Fig. 2 上図, Fig. 3 上図 に示す．櫛挽断層付近の重力異常は特異なパターンをしているが，これはこの付近の北東一南 西方向の重力異常の一般的傾向が双曲線的であることと, 北東側隆起の櫛挽断層による重力異 常とが重なつているためである.このことを Fig. 4 に模式的に示す. 図で A-A' は重力異 常の一般的傾向, B-B' は断層による重力異常とする. 両者を重ね合せたものが黒丸で表わさ れた観測值に相当する重力異常である.この図から重力異常の一般的傾向が $\mathrm{A}-\mathrm{C}^{\prime}$ でなくて, $\mathrm{A}-\mathrm{A}^{\prime}$ あるいは $\mathrm{C}-\mathrm{C}^{\prime}$ であること, 断層による重力異常のオフセットが $\left(\mathrm{A}-\mathrm{A}^{\prime}\right)$ と $\left(\mathrm{C}-\mathrm{C}^{\prime}\right)$ との差であることがわかる.このようにして求めた残差重力異常を Fig. 2 下図, Fig. 3 下図 に示す. A-A 測線 (Fig. 2 下図) では櫛挽断層で 8 ミリガル, 深谷断層で 3 ミリガルの重 力異常が，B-B' 測線 (Fig. 3 下図) では櫛挽断層で 6 ミリガル，深谷断層で 2 ミリガルの

$$
B-B^{\prime} \text { PROFILE }
$$
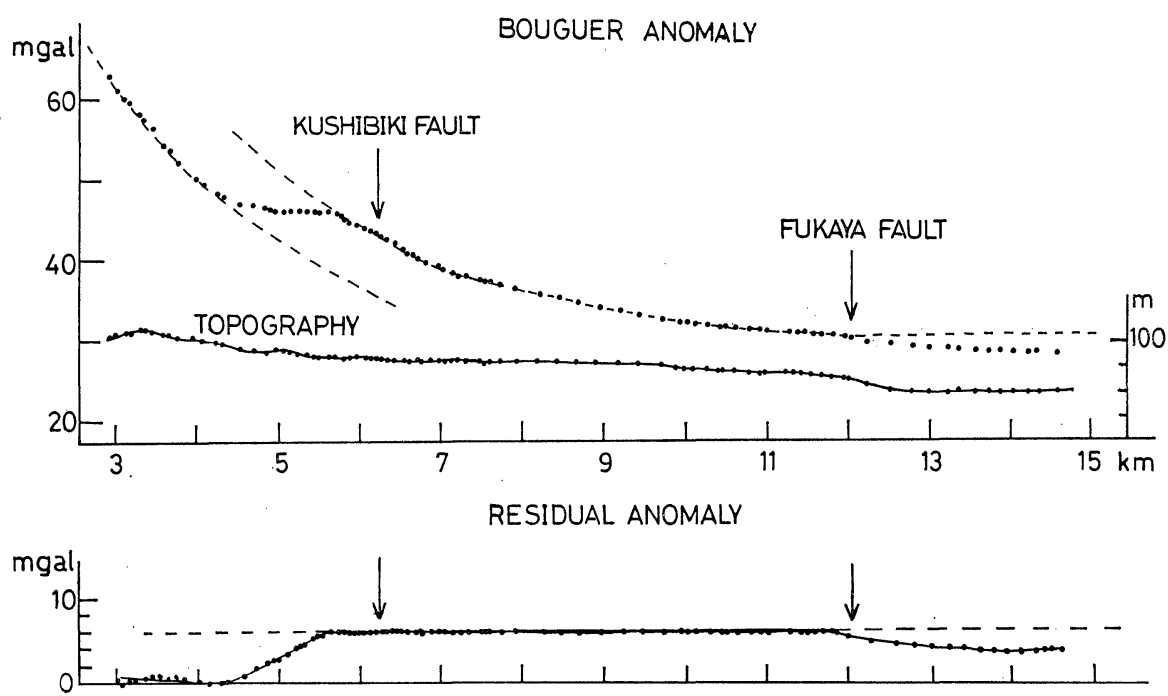

Fig. 3. Bouguer gravity anomaly and residual gravity anomaly in the B-B' profile across the Kushibiki and the Fukaya faults. 


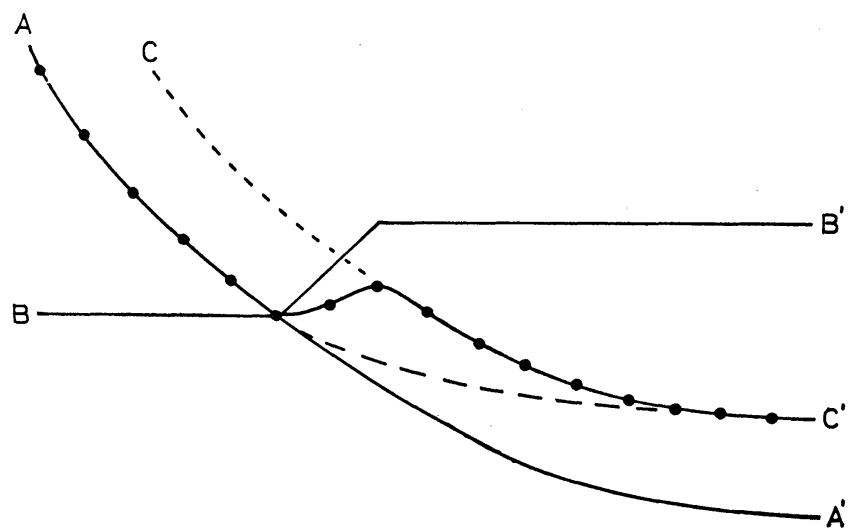

Fig. 4. Schematic illustration of the gravity anomaly caused by fault offset. A-A': general trend of gravity field. B-B': gravity anomaly caused by fault offset. $A-C^{\prime}$ : superposed $\mathrm{A}-\mathrm{A}^{\prime}$ and $\mathrm{B}-\mathrm{B}^{\prime}$ (=observed gravity anomaly).

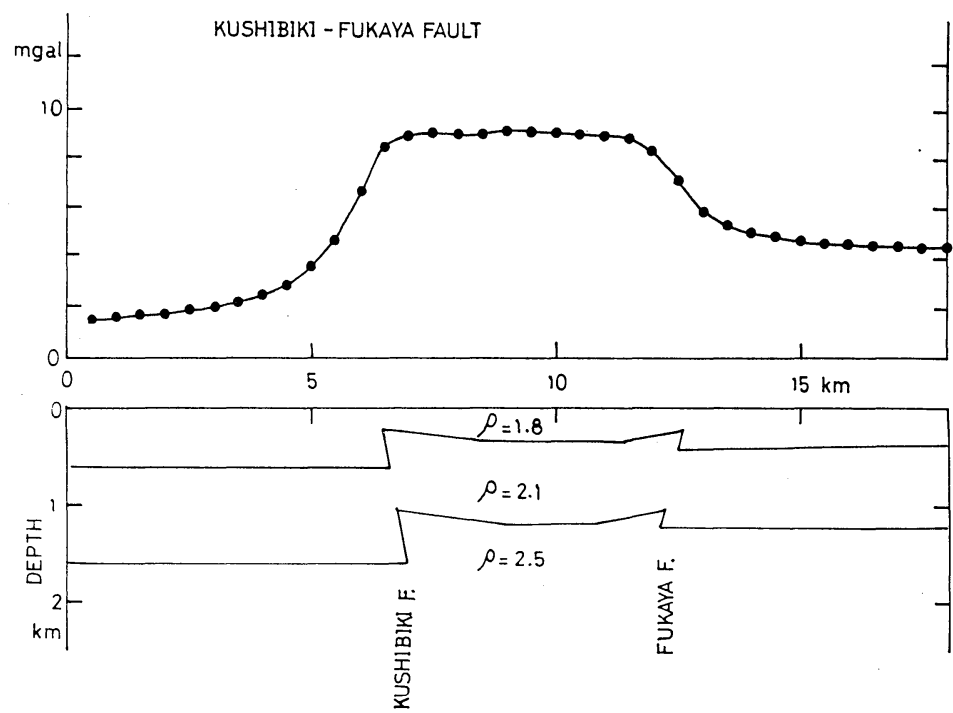

Fig. 5. Underground structure and calculated gravity anomaly in the $A-\mathrm{A}^{\prime}$ profile across the Kushibiki and the Fukaya faults.

重力異常が認められる.これらの重力異常を地表の断層地形, 地質で説明することは不可能で, これらが地下深部の構造異常によるものであることは明らかであろう. A-A' 測線の重力異常 を説明する地下構造モデルの一つを Fig. 5 に示す. 層構造や密度の仮定の仕方にもよるが, 地下 $1 \mathrm{~km}$ 位の深部における櫛挽断層, 深谷断層の变位量はそれぞれ約 $500 \mathrm{~m}$, 約 $200 \mathrm{~m}$ 位 と推定され，地下深部での变位量は櫛挽断層の方が深谷断層よりもかなり大きい.

櫛挽断層の南東端は松田 (時) ・他 (1975), 活断層研究会 (1980) に上ると, 寄居町三軒家付 近にあつて Fig. 2 に示される A-A' 測線とは交叉しない. しかし, 松田博・他 (1977) によ ると櫛挽断層はさらに南東の深谷市下郷付近まで延びており, Fig. 2 の櫛挽断層はこの記載に 
従つている. Fig. 2 の重力異常をみ るかぎり基盤の断層は深谷市下郷付近 には確実に存在しており, 重力異常は 松田博・他 (1977) の記載を支持する. このことは重力探査が活断層調査の有 力な手段であることを示すものである. $\mathrm{A}-\mathrm{A}^{\prime}$ 測線の重力異常からみて櫛挽断 層はさらに南東方向へ続いており，荒 川左岸まで達している可能性がある。

Fig. 6 は断層による重力異常の表 われ方を模式的に示したもので，Fig.

2, Fig. 3 の櫛挽断層, 深谷断層は図の $\mathrm{b}, \mathrm{b}^{\prime}$ の断層で A のパターンの場合である. 重力異 常のパターンのみでは断層のタイプを一意的に決めることは困難であるが，Fig. 6 のような コンターマップのパターンは縦ずれ断層の有無を示す重要な情報である.

深谷断層の変位速度分布 [垣見・他 (1981)] によると，その北西端では変位速度は小さく， 重力異常も小さい (Fig. 3) ので，北西端は実際に断層の末端部に近いと考えられる. しかし， 南東端（熊ヶ谷市三ヶ尻付近）の変位速度は最大に近かく, 三ヶ尻以南は荒川の堆積層におお われて断層は認められないが，深谷断層の主要部は三ヶ尻以南に存在することが予想され，断 層は荒川を越えてさらに南東方向に続くものと思われる.

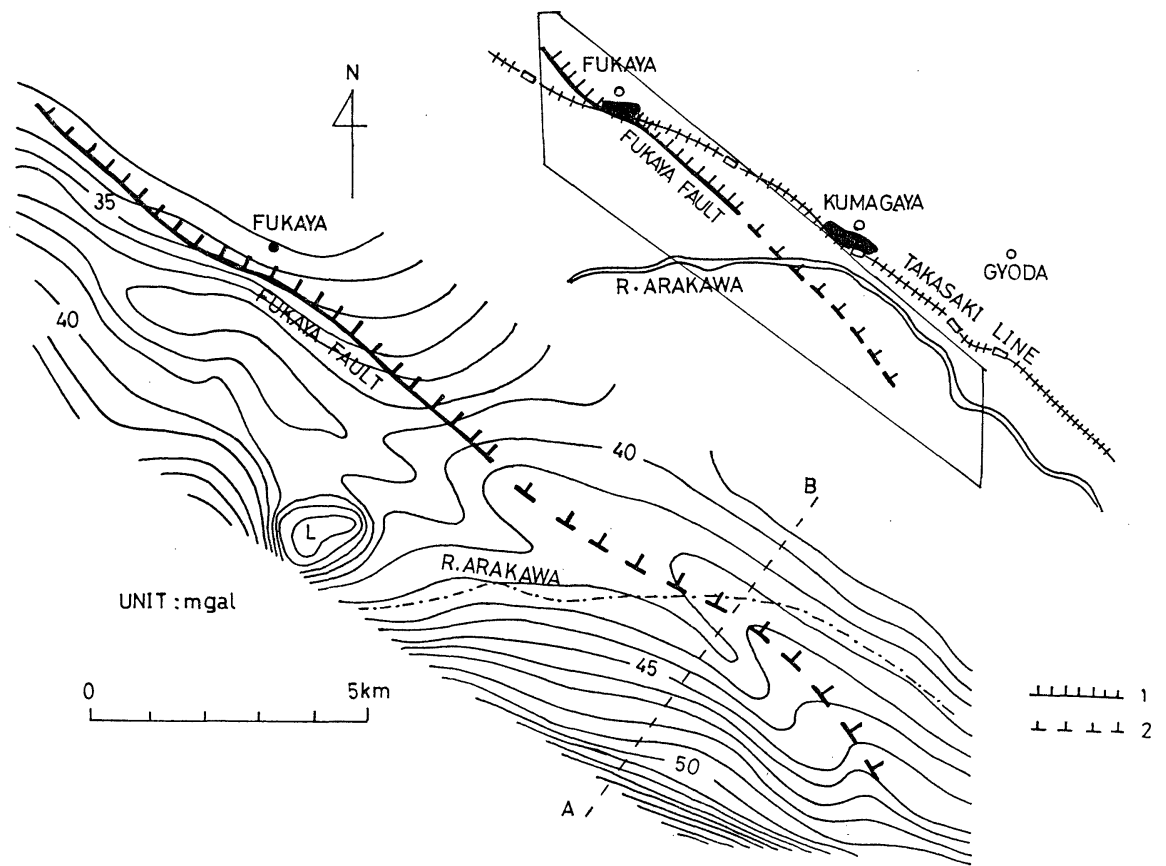

Fig. 7. Bouguer gravity anomaly map along the Fukaya fault and its extended fault. Note the anomalous contour lines along the fault. 
Fig. 7 は深谷断層を含む地域の重力異常図で, 深谷断層の南東延長上に Fig. 6 B に示さ れる特徴的なパターンがみられる。このパターンは荒川を越えて南東方向に埼玉県大里村下恩 田付近をで約 $10 \mathrm{~km}$ にわたつて追跡できる.このパターンは走向が北西一南東方向で南西側 隆起の基盤断層の存在を示すもので, Fig. 7 の点線で示される位置付近に基盤断層が存在する ものと思われる．この位置は深谷断層の南東延長上にあたることから，この基盤断層は深谷断 層の延長部と旨定される.この部分が活断層であるかどうかはこのデータだけからでは判断で きないので，ボーリング調查や地形調査などを詳しく行なう必要がある．仮にこの延長部を活 断層であるとすると深谷断層の総延長は約 $20 \mathrm{~km}$ と 2 倍になるので，想定マグニチュードな ども再考せねばならないだろう。

Fig. 2, Fig. 3, Fig. 7 の重力異常をみるかぎり, 基盤での変位量は櫛挽断層の方が深谷断 層よりも大きい。地形およびボーリング調査による櫛挽断層の変位量は地表で $2 \sim 5 \mathrm{~m}$, 深さ $60 \mathrm{~m}$ 付近で約 $6 \mathrm{~m}$ で, 深谷断層では地表で $5 \sim 14 \mathrm{~m}$, 深さ $30 \mathrm{~m}$ 付近で $25 \sim 30 \mathrm{~m}$, 深さ $70 \mathrm{~m}$ 付近で 40 50 m となつており [垣見・他 (1981)]，変位の累積性が認められるが，地表付近 の変位量は深谷断層が櫛挽断層よりも大きい.変位速度も深谷断層の方が櫛挽断層よりも早い [活断層研究会 (1980)]. このように地下深部では櫛挽断層の変位量が深谷断層の変位量よりも 大きいにもかかわらず，地表付近での変位量や変位速度は逆に深谷断層の方が大きくなつてい る.このことは深谷断層の方が櫛挽断層よりも新らしく，かつ活動度が高いということ，ある いは，同じ古さなら，古い時代では櫛挽断層の方が活動度が高く, 新らしい時代では深谷断層 の方が活動的である，ということを表わしている.いずれにしても近接した活断層どうしでも 活動度が時代によつて異なつているということは興味深いことである.

\section{§3. 立川断層と重力異常}

狭山丘陵西端を通り立川市へ抜ける北西一南東方向の直線状のゆるやかな崖(北東側隆起)の 存在は古くから知られており，1654 年（承応 3 年）に完成した玉川上水もこの崖の所（立川 市砂川町三番）で过回を余儀なくされている．この崖が活断層であることを最初に指摘し，立 川断層 (Fig. 1-7) と命名したのは松田博・他 (1975) である. 立川断層の総延長は約 $20 \mathrm{~km}$, 北東側隆起の逆断層で上総層群の垂直変位量は最大 $70 \mathrm{~m}$, 横ずれ成分はみられなく, 確実度 $\mathrm{I}$ 活動度 B 級と推定されている [活断層研究会 (1980)]. 東京近辺で存在が確実な活断層はこの 立川断層だけで，東京とその周辺の地震予知を考える上で重要である．ここでは地形学的な記 載とは別に地球物理学的な観点から立川断層の形態について述べる.

立川断層は関東山地東縁の埼玉県入間付近から南東方向に狭山丘陵を通り, 多摩川を横断し 横浜西部に達する地溝状の落ちこみ「入間一横浜地溝」(多田 (1982)]の北部西側斜面に位置し ている. 立川断層は重力異常図で存在が認められる断層の典型例である. Fig. 8 は首都圈にお ける活断層調査のために作成されたブーゲ重力異常図 [国土地理院・国立防災科学技術センタ - (1979)] である. 図の中央左の枠中の箇所に Fig. 6 に示されるコンターラインの「ゆがみ」 がみられるが，このコンターラインのパターンは南西側隆起で走向が北西南東方向の断層の存 在を示すものである. このパターンは東京都瑞穂町から立川市を通り府中市まで約 $20 \mathrm{~km}$ に わたつて追跡できる. パターンの位置および長さは地形的な立川断層のそれに一致している. しかし地形的な立川断層は北東側隆起で, 重力異常から推定される基盤断層とは反対になつて 


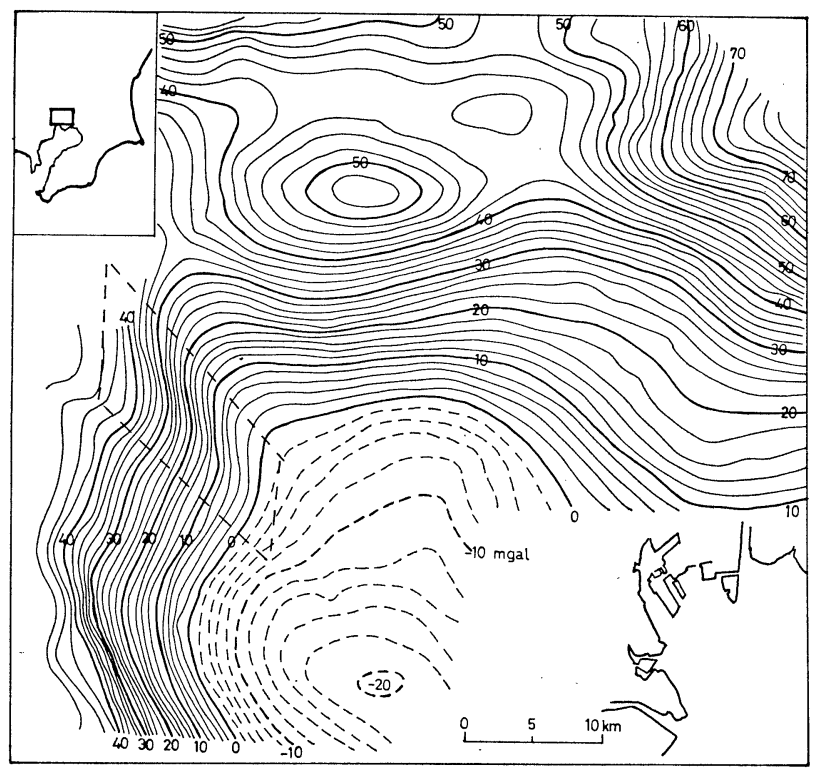

Fig. 8. Precise Bouguer gravity anomaly map in the Metropolitan area (after Geographical Survey Institute and National Research Center for Disaster Prevention, 1979). Rectangle shows the anomalous contour lines along the Tachikawa fault.

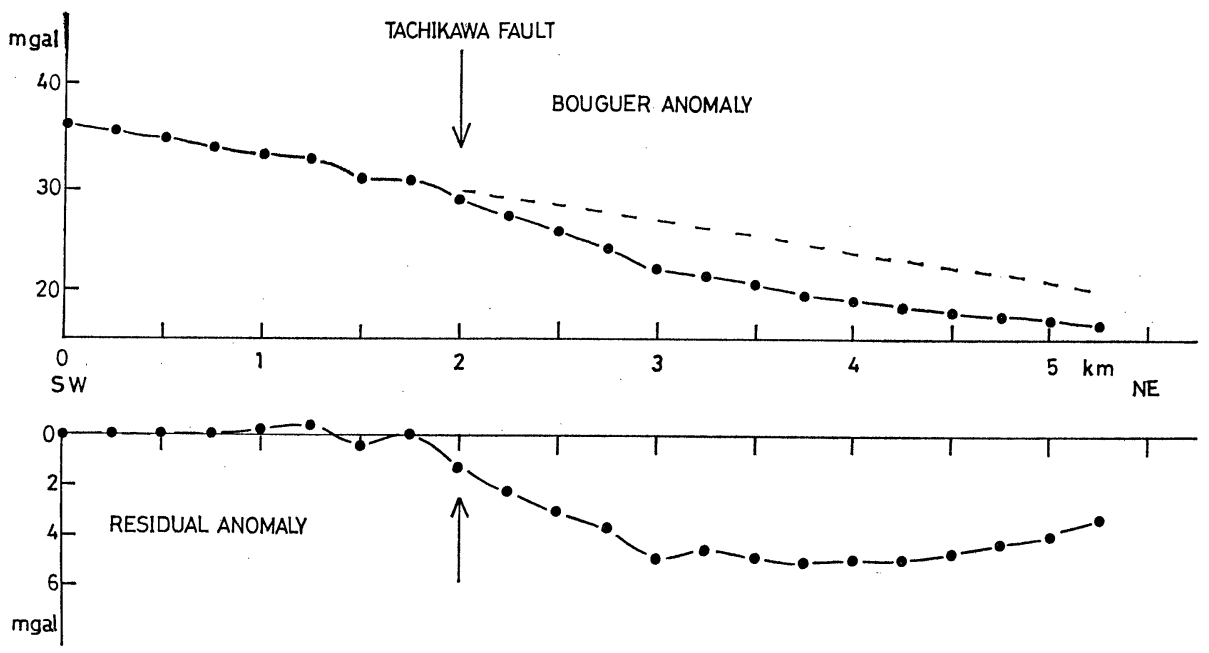

Fig. 9. Bouguer gravity anomaly and residual gravity anomaly in the profile across the Tachikawa fault.

いる. Fig. 9 は立川市付近で断層に直交する方向に断面をとつた立川断層近辺の重力異常プ ロファイルで，断層を境にして約 5 ミリガルの南西側隆起の重力差がみられる. この重力差は 基盤では約 $500 \mathrm{~m}$ の落差に相当する.

関東平野の基艋構造 [多田 (1982)] と Fig. 9 の重力異常から求めた立川断層に直交する方 


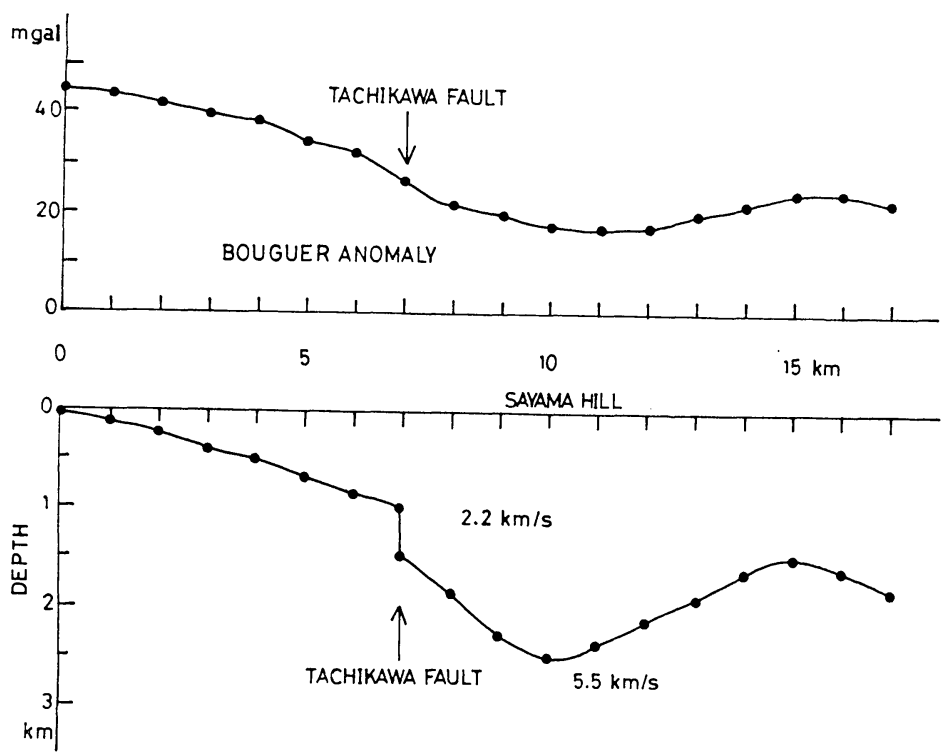

Fig. 10. Underground structure and observed gravity anomaly in the cross section of the Tachikawa fault.

向の地下構造を Fig. 10 に示す. 基盤断層が地溝の西側斜面に位置し, 北東側落ち(おそらく 正断層) $400 \sim 500 \mathrm{~m}$ の断層であることは明らかであろう.

一般的にいつて, 重力異常から求められる基盤断層は古い時代の断層運動の痕跡である. 立 川断層の地表と基盤の落差の方向が異なつているということは，古い時代と新らしい時代で断 層運動の形態が異なつていることを示しているといえよう．即ち立川断層が地溝の斜面上に位 置すること, 基盤断層の落差の方向から立川断層の基盤断層は地溝の成因に関係した古い断層 であつて，活断層としての立川断層はこの古い断層の傷跡が最近の応力状態に支配されて，再 活動しているものと考兄いる.

立川断層を震源とする被害地震はないが，その活動度は首都圏直下型地震の予知にとつて重 要な要素である. 国土地理院ではこの断層周辺に精密変歪観測網を設け, 測量を続けているが, 今のところ測量誤差を上まわる变動は観測されていない[多田・他 (1978)].

\section{§4. 人工地震探查による基盤断層}

前報 [多田 (1982)] によつて関東平野の基盤に多くの断層構造があることが判明したが，こ れらの基盤断層と活断層との関連について考察する.

Fig. 11 上図は夢の島-吉川測線の地下構造で夢の島北方約 $20 \mathrm{~m}$ のところに北側隆起の落 差約 $500 \mathrm{~m}$ の基盤断層がみられる.この断層は東京都足立区と埼玉県八潮市の都県境付近に 位置している. Fig. 11 中図は夢の島一筑波山測線の地下構造で, 夢の島から約 $17 \mathrm{~km}$ の東京 都葛飾区と千葉県松戸市の都県境の江戸川「矢切の渡し」付近に北側隆起で落差約 $500 \mathrm{~m}$ の 基盤断層がある. Fig. 11 下図の夢の島一八千代測線の地下構造で夢の島から約 $16 \mathrm{~km}$ の地点 （千葉県船橋市）に北東隆起の落差約 $500 \mathrm{~m}$ の基盤断層がある.この断層は榆井 (1980) の船 

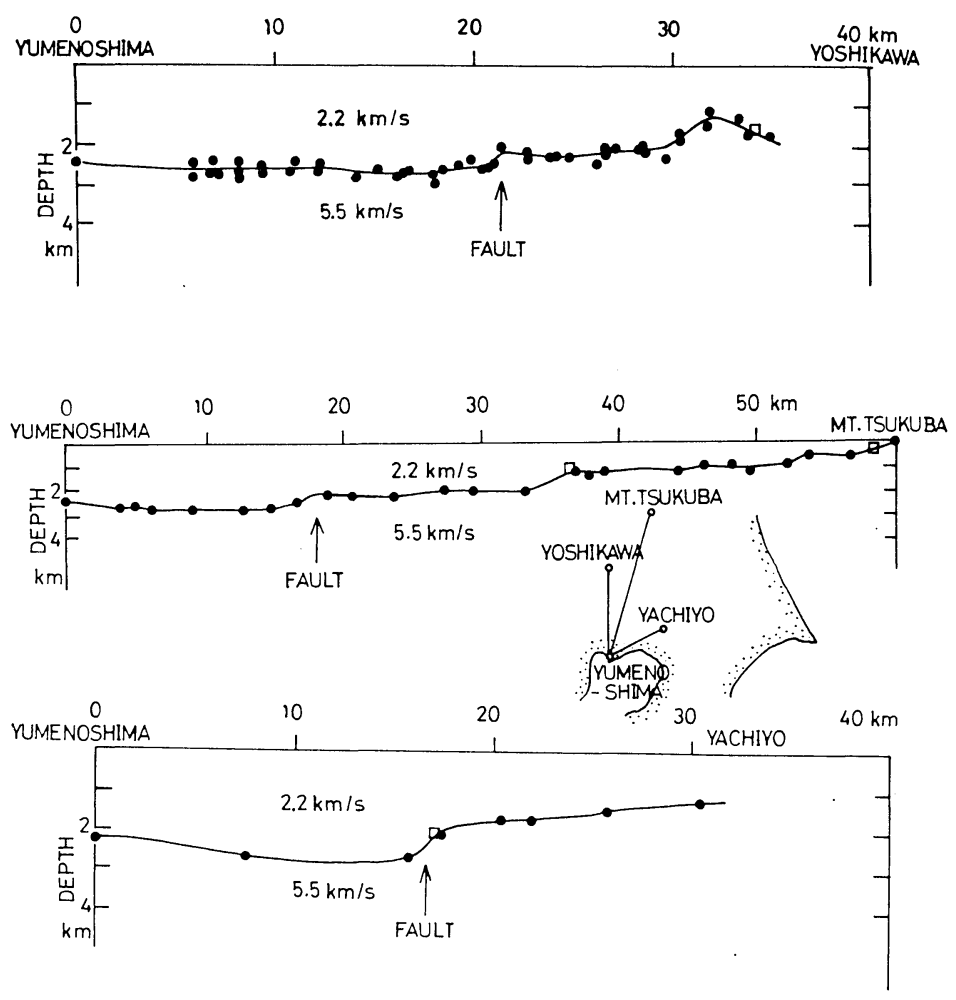

Fig. 11. Underground structures in the profiles of Yumenoshima-Yoshikawa (upper),-Mt. Tsukuba (middle) and -Yachiyo (lower) (after TADA, 1982). Arrows indicate the faults.

橋付近の基盤断層と同一のものであろら．これら三本の基艋断層は北西南東方向にほぼ直線上 に並らび，すべて北東側隆起なので，一続きの断層と考えられる (Fig. 15 参照).

この断層に沿つての東京湾北東岸の地表には下総台地の南西縁をなす段丘崖が存在しており, 活断層の疑いのある撓曲崖といわれている．この撓曲崖の地下深部に基盤断層が確認されたこ とにより，この撓曲崖は断層運動によつて生じた活構造と判明した。従つて，これらの基盤断 層, 撓曲崖は活断層であるといえる，撓曲崖は千葉市付近まで続いており，基盤断層，撓曲崖 から，この活断層は総延長約 $35 \mathrm{~km}$, 北東側隆起で, ほぼ東京湾北東岸に沿つている.この活 断層を「八潮一千葉断層」と名付けておく，八潮-千葉断層は京葉地区の中心に位置しているが， 活動度など詳細は不明であり, 精査する必要がある.

次に夢の島から南西方向への人工地震探查の結果 [瀬尾・小林 (1980), 瀬尾 (1981), 多田 (1982)] を Fig. 12 に示す. 図中矢印の位置に北東側隆起の落差約 $500 \mathrm{~m}$ 位の基盤断層がみ られるが，その位置は横浜南西部の地溝 (入間-横浜地溝) の北東斜面で，これらの断層が一 本の断層である可能性が大きい (Fig. 15 参照). 注ぼ鶴見川に沿つているので，「鶴見川断層」 と名付ける．立川断層が入間一横浜地溝の南西側斜面に位置しているのに対して，鶴見川断層 は北東側斜面に位置しており，これらの事実は入間-横浜地溝が断層運動によつて生じた可能 性を示唆している. 

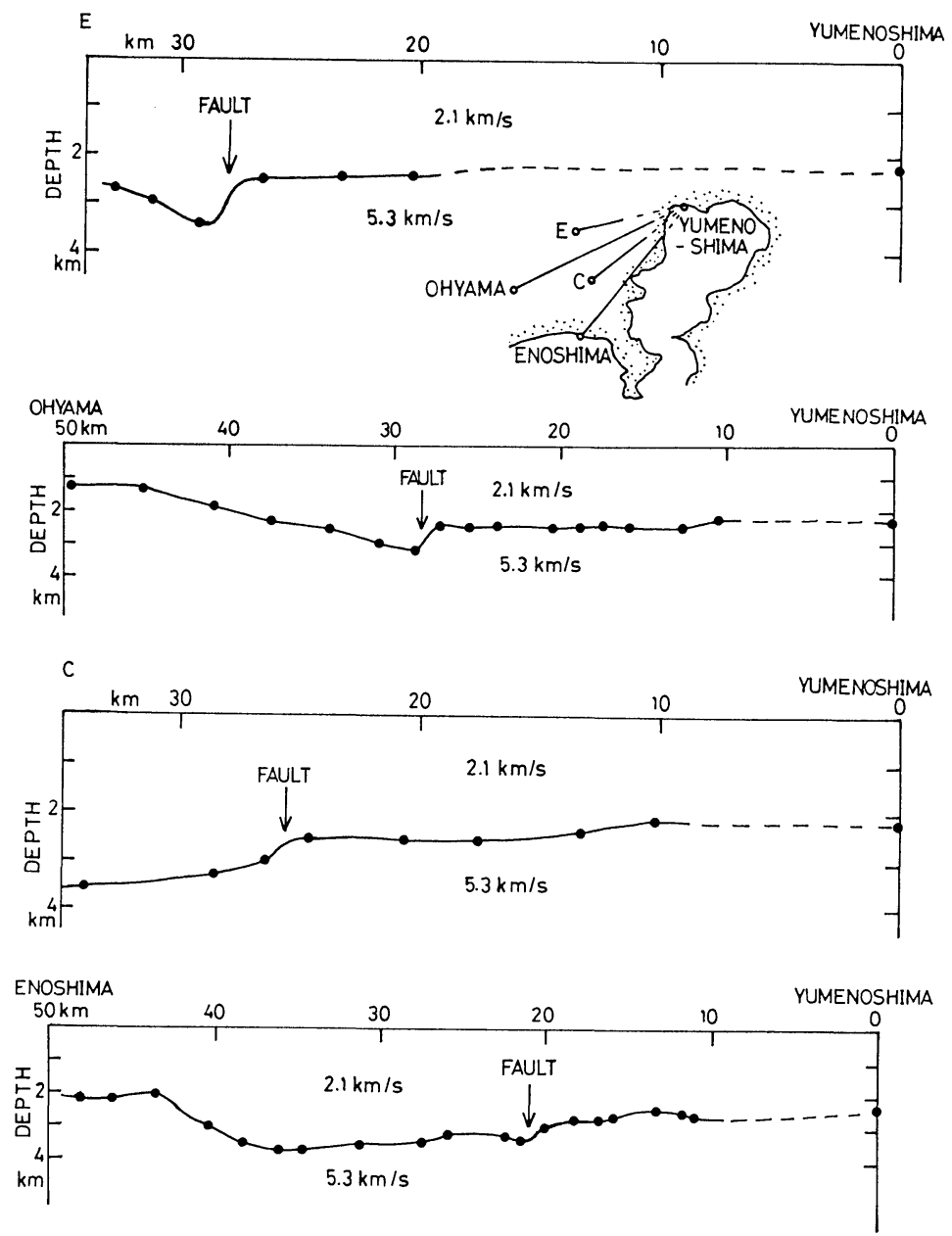

Fig. 12. Underground structures in the southwestern part of Kanto plain (after SEO and KobaYASHI, 1980, SEO, 1981 and TADA, 1982). Arrows indicate the faults.

鶴見川断層は多摩丘陵中に位置しているが，リニアメントなどの活構造地形は今のところ知 られていない。古い基盤断層のみで活断層ではない可能性が強いが，地形など再調查する必要 もあろら。

\section{$\S 5$. 荒川断層と基盤構造}

荒川をはさんで東西に位置する大宮台地と武蔵野台地との間には $10 \sim 15 \mathrm{~m}$ の標高差があり， 相対的に大宮台地が隆起しており，このことを根拠にして荒川沿いに北東側（大宮台地側）隆 起の「荒川断層」(Fig. 1-6) の存在が推定されている [貝塚 (1957)]. 貝塚・他 (1977), 活断 層研究会 (1980) によれば, 荒川断層は埼玉県川島町から浦和市まで総延長約 $20 \mathrm{~km}$, 確実度 II, 活動度 B 級の活断層であるが，関東平野の厚い沖積層下にあるため正確な位置は不明であ る. 浦和以南では断層は確認されていないが，延長部についてはボーリング資料による推定が 


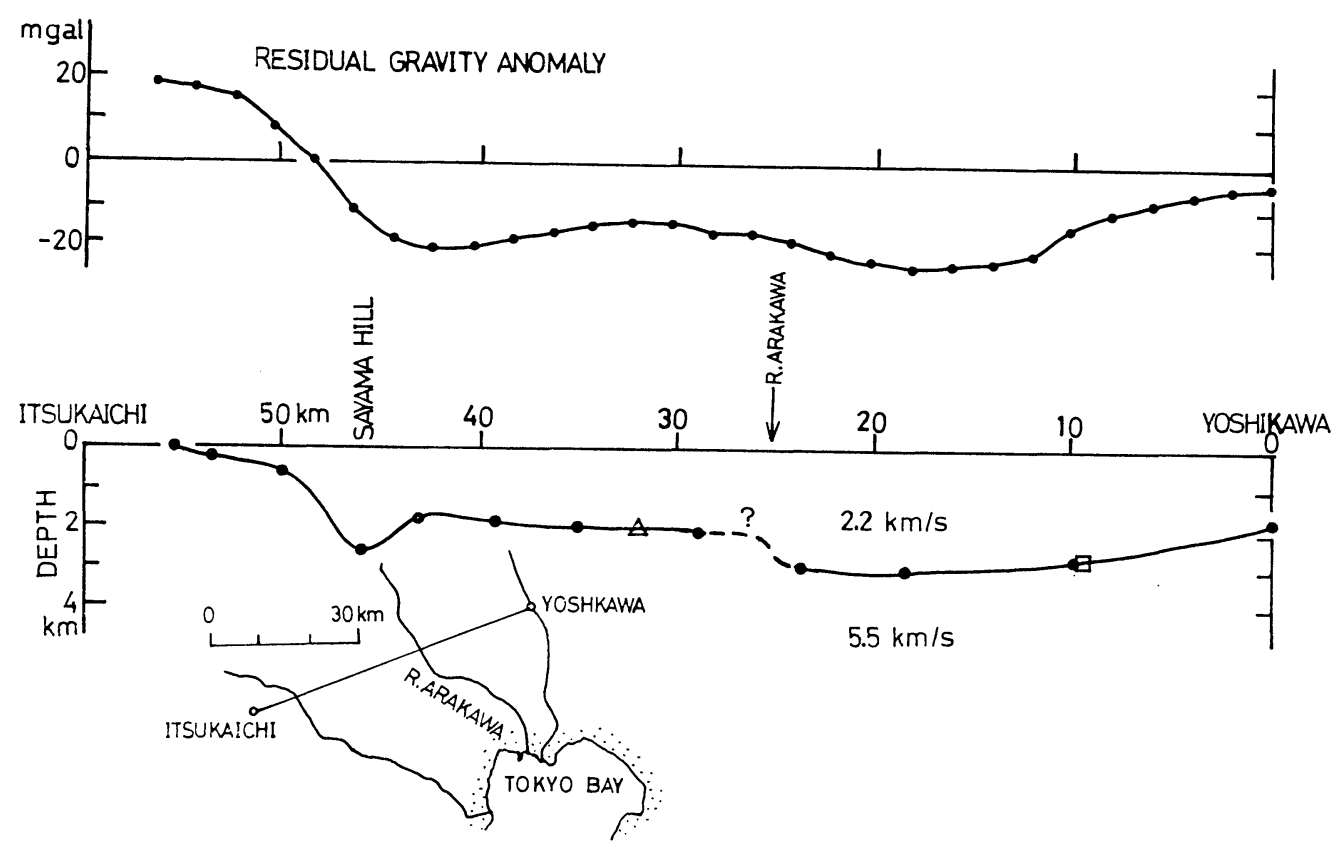

Fig. 13. Undergraound structure in the Yoshikawa-Itsukaichi proffle across the Arakawa fault (after TADA, 1982). Note the fault structure beneath the River Arakawa and depth of the basement both side of the fault.

ある [貝塚・他 (1977)]．荒川断層についてはその存在を積極的に支持する他の地形的な証拠は なく，存在そのものを疑問視する研究 [垣見・他，1981］もある.ここでは地震探査，重力探 査から荒川断層汇ついて考察する.

前章までにみてきたように，地形から活断層と認められている断層はすべてその地下深部に 基盤断層を伴なつている．「活断層は基盤断層を伴なつている」ということの逆は必らずしも成 り立たないが，基盤断層の存在は地表に活断層が存在する可能性を示すものである．従つて地 形学的に活断層を調査することが困難な平野部では，まず物理探査手法で基盤断層を検出する ことが有効な手順である.

吉川一五日市測線は現在のところ荒川断層を横断する唯一の人工地震測線で，吉川から 23 $24 \mathrm{~km}$ の浦和付近で断層を横切るものと思われる. Fig. 13 にこの測線の地下構造 [多田(1982)] を示すが，荒川や荒川断層付近には地形から期待される南東側（大宮台地側）隆起の基盤構造 やそれに対応する重力異常は認められず，むしろ南西側（武藏野台地側）隆起の断層構造がみ られる。

夢の島一吉川測線は夢の島から 15 16 km の地点で荒川断層の推定延長部 [貝塚・他 (1977)] と交わると思われるが，地下構造（Fig. 11）には断層構造は認められず，基盤深度は南側に向 つて浅くなる傾向にある.

次に関東平野下に潜在するかも知れない活断層を検出する目的で作成された Fig. 8 の重力 異常図に瀬谷のフィルターをかけて, 波長数 $\mathrm{km}$ 程度の正規構造を求め荒川流域の基盤の形状 を詳しくみてみた。その結果を Fig. 14 に示すが，大局的にみて荒川の南西側（武蔵野台地 


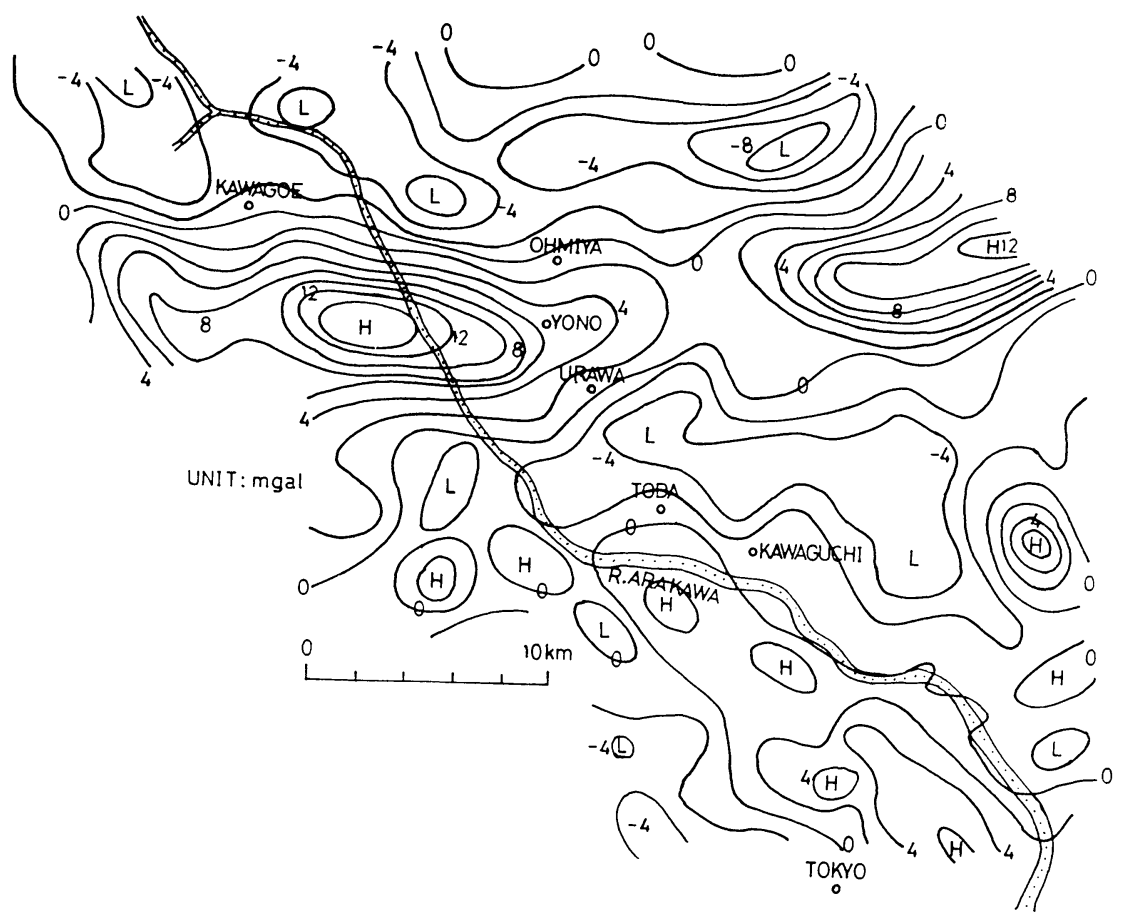

Fig. 14. High pass filtered gravity anomaly map along the River Arakawa obtained by Seya's method. Original map is shown in Fig. 8. Depth of the basement in the west side of river is shallower than that of the east side.

側）の基盤が浅くなつており，上述の地震探査による基盤構造や関東平野の基盤構造図と調和 的である.

このように地震探査, 重力探査からは荒川断層の推定位置付近に地形から予想されるような 北東側（大宮台地側）隆起の基盤断層はなく，むしろ南西側（武蔵野台地側）隆起の基盤断層 がみられる．また浦和以南の推定延長部には基盤断層はみられない，立川断層の例にみられる ように地表の断層の形態と基盤断層の形態とが異なるという逆転現象があるので，荒川断層に ついても必らずしも活断層の存在を否定するものではないが，台地のような規模の大きな地形 まで逆転現象が成り立つかどうか疑問である，仮に活断層としての荒川断層が存在するとして も, その基盤断層は南西側（武蔵野台地側）隆起で, 浦和以南には延びていないと推定される. また地形的な断層も南西側（武蔵野台地側）隆起の可能性もある.いずれにせよ精査すべきで ある.

\section{§6. 議論および結論}

前報 [多田 (1982)] および今回の結果から関東平野の基盤構造がかなり詳しくわかつてきた. Fig. 15 にこれまで得られた結果をまとめて図示する.この関東平野の基盤構造から関東造盆 地運動, その他のテクトニクスなどを議論することも可能であると考えられるが, 詳しい議論 は次の機会にゆずることにして，ここでは 1,2 のことについて簡単に触れるだけにとどめる. 


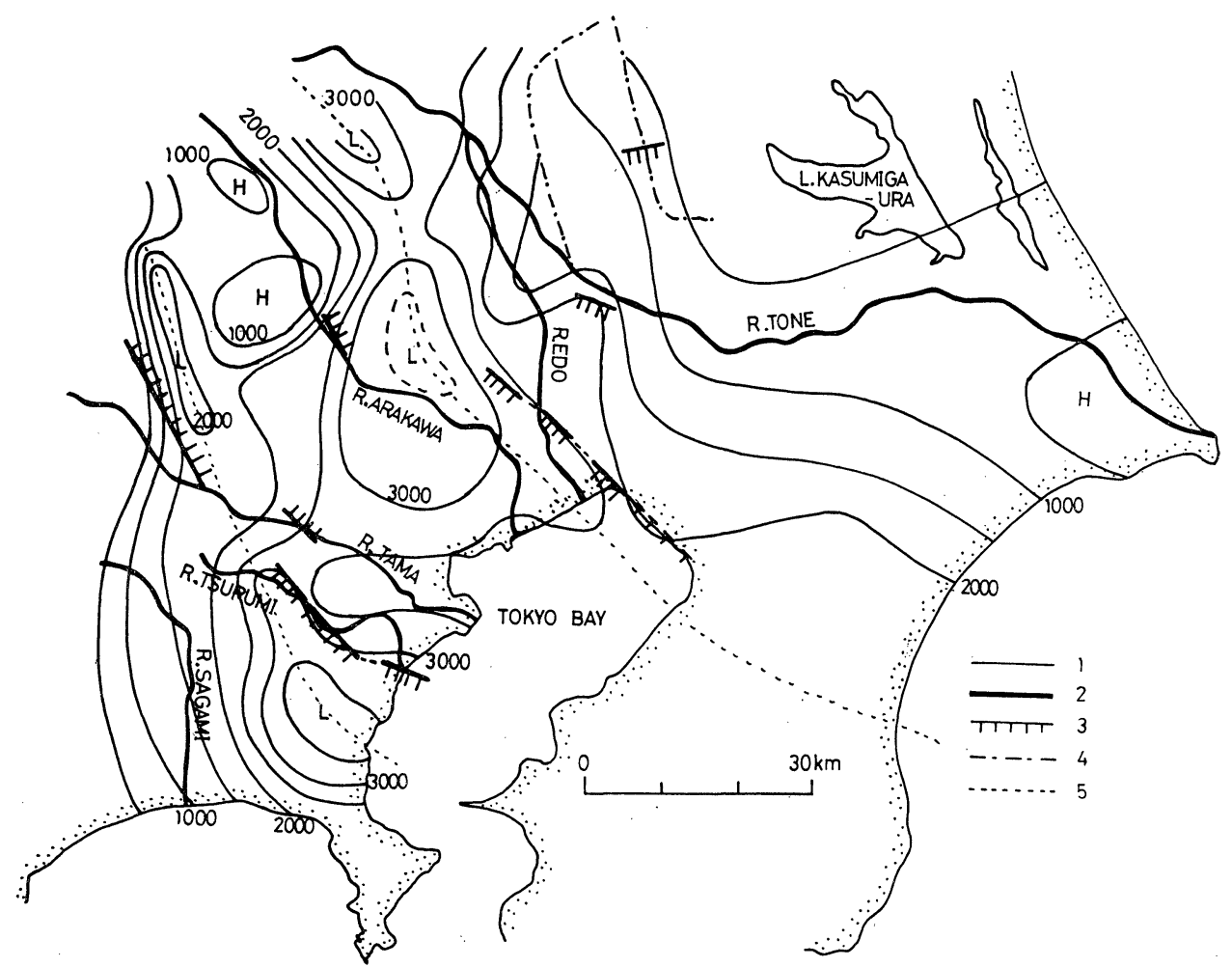

Fig. 15. Structure of the basement beneath the Kanto plain (modified from TADA, 1982 and added by this study). 1: contour line. 2: river. 3: fault in basebent. 4: KarasuyamaSugonuma fault. 5: axis of subsidence in basement.

Fig. 15 の基盤構造図には 2 本の沈降軸が認められる．東側のものは熊谷-春日部-浦安を通る もので，この南東延長は房総半島市原一茂原を結ぶ線に沿ら 房総半島北部の基盤およびその下 の層の構造的な落ちこみ [多田 (1976)] に続き，さらに太平洋の海底谷に続くものと思われる. この沈降軸は石井 (1962) の第三紀沈降軸と同じものであろう.データや解析方法が異なつて 同じ結果が得られているので，この沈降軸の存在は確実である．八潮-千葉断層，荒川断層が この沈降軸の両側に位置し, 並走していることは興味深いことで, あるいはこれらの断層が沈 降軸の成因に関係しているのかも知孔ない。る一本の沈降軸は入間-横浜地溝で, 立川断層, 鶴見川断層もこの沈降軸の成因に関係しているものであろう。これらの沈降軸は中央構造線よ りも相模トラフに平行しており，その成因とフィリピン海プレートのサブダクションの間に何 らかの因果関係があることが示唆される. また基盤断層や活断層のいくつかは沈みこんでいる フィリピン海プレートに衝上しているユーラシアプレート内の高角逆断層, 即ち関東大地震を 起こす断層面（メインスラスト）から枝分れした副断層である可能性も考えられる. 今後これ らの観点から関東平野の基盤構造, 活断層を議論すべきであろう.

内陸部に発生した規模の大きな地震についてはその断層モデルが決められている．それらの 結果によれば，断層の幅は $10 \sim 20 \mathrm{~km}$ で，基盤面はもちろん， $6 \mathrm{~km} / \mathrm{s}$ 層の上面境界，場合 
によつてはコンラッド面まで切つている.この地震断層が第四紀を通じて活動していたとすれ ば, その累積変位量は数 $100 \mathrm{~m}$ に達し, 基盤面やさらに深部に数 $100 \mathrm{~m}$ の変位があつて当然 である. 地震探査, 重力探査から関東平野の活断層は地下深部に落差数 $1000 \mathrm{~m}$ の基盤断層を 伴なつていることが判明し，上述の推定が正しいことを示している．このことの意義は大きい. 何故なら基盤断層の存在の有無が活断層調査の有力な手掛りとなるからである. 即ら, 地形学 的に活断層の調査が困難な平野部においては，まず基盤断層の有無を人工地震や重力探査で明 らかにし，もし基盤断層が存在すれば，さらに詳しくボーリング調查などの従来の手法で調査 するといら手順が有効である. また，物理探査によつて求められた基盤断層の変位量と地表の 変位量の比較から活断層の活動度 (活動歴) の推定が可能なことも判明した.

これらの結果は人工地震探査や重力探査などの地球物理学的手法を活断層調査の基礎的な手 法として, 意識的に用いることの重要性を示している. そのためには地殼構造を研究している 研究者の積極的な活断層調査への参加が必要である.

\section{謝 辞}

活断層の露頭観察などでお世話になつた国土地理院羽田野誠一, 松田博の両氏に深く感謝致 します。深谷，櫛挽断層预よび首都圏地域の重力測定は昭和 50 年 53 年度科学技術庁特別 研究促進調整費によつて実施された（課題名：平野部における活断層探査手法および活断層の 活動度に関する総合研究).

\section{文献}

石井基裕, 1962, 関東平野の基盤，石油技術協会誌，27，615-640.

貝塚爽平, 1957, 武蔵野台地の地形变位とその関東造盆地運動における意義, 第四紀研究, 1, 20-30. 貝塚㸚平・松田時彦・町田 洋・松田磐余・菊地隆男 - 丸田英明 - 山崎晴男・村田明美, 1977, 首都 圈の活構造, 東京直下地震に関する調査・研究 (その 4), 165-220, 東京都.

垣見俊弘・森 和雄・山崎晴男 - 矢崎清貫 - 福田 理 - 小玉喜三郎・鈴木尉元・周 重文・桂島 茂, 1981，平野部活断層に関する資料調査及び地形・地質調査，平野部における活断層探査手法拉よ び活断層の活動度に関する総合研究報告書, 16-31, 科学技術庁.

活断層研究会, 1980 , 日本の活断層一分布図々資料, $363 \mathrm{pp}$, 東京大学出版会.

国土地理院・国立防災科学技術センター, 1979, 首都圈精密ブーゲ重力異常図, 国土地理院.

松田 博・羽田野誠一, 1975, 関東平野西辺の線状構造, 日本地理学会予稿集, 8.

松田 博・羽田野誠一・星埜由尚, 1977, 関東平野とその周辺の活断層と主要な構造性線状地形につ 、て, 地学雑誌, 86, 92-109.

松田時彦・山崎晴男・金子史朗， 1975，西関東の活断層，東京直下地震に関する調査・研究（その 2), 75-108, 東京都.

榆井 久, 1980, 地盤上昇現象について, 地震, 259-270, 東海大学出版会.

瀬尾和大・小林啓美, 1980 , 人工地震による首都圈南西部の地下深部探査, 地震 $2,33,23-36$.

瀬尾和大, 1981, 地下深部の地盤構造が地表の地震動に及ぼす影響, 東京工業大学学位論文.

多田 堯, 1976, 関東平野の地下構造について, 地震 2, 29, 47-53.

多田 蕘・石井晴男・海津 優, 1978, 平野部に扑ける活断層探査手法および活断層の活動 度の研究一，国土地理院調査・研究報告, 3-11-1 3-11-21, 国土地理院.

多田 堯, 1982, 関東平野の基盤構造と重力異常 (1)一基盤深度図一, 地震 2, 35, 607-617.

地震予知連絡会, 1980, 首都及びその周辺の地震予知, 地震予知連絡会地域部会報告, $2,82 \mathrm{pp}$, 国土 地理院. 